\title{
Plus ça change: Change and continuity at the International Review of Education
}

\author{
Stephen Roche
}

Published online: 11 July 2013

(C) Springer Science+Business Media Dordrecht and UNESCO Institute for Lifelong Learning 2013

In fifty-eight years of unbroken publication, ${ }^{1}$ the International Review of Education $(I R E)$ has run the gamut of themes in international comparative education. In its first year of publication alone (1955), we published articles on vocational and teacher education, media and leisure, theory and philosophy of education, political and parental education, language of instruction and youth disengagement. Though almost two decades would pass before the IRE explicitly broached the subject of lifelong learning, it is clear that this was always a broad palette. The 1974 special issue on "Lifelong Education and Learning Strategies" took up the key messages of the Faure Report, which launched the idea of lifelong learning as "the master concept for educational policies in the years to come" (Faure et al. 1972, p. 182). The editors' introduction to that issue, by Ravindra Dave and Paul Lengrand, staked out the parameters of lifelong learning: "It encompasses all stages and forms of learning - whether in the home, school, community or through the mass media - in an integrated and articulated manner" (Dave and Lengrand 1974, p. 427).

By the time the UNESCO Institute for Education was reconstituted in 2006 as the UNESCO Institute for Lifelong Learning (UIL), the IRE was already well established as an international forum for applied research in lifelong and life-wide education. With this existing tradition in mind, the Governing Board of UIL, at its recent meeting in March 2013, decided to adopt the subtitle "Journal of Lifelong Learning". This does not represent a change of direction as much as an explicit recognition that the $I R E$ is dedicated to a vision of education that embraces the "flexibility, diversity, universality and dynamism" of the lifelong learning paradigm

\footnotetext{
${ }^{1}$ Strictly speaking, this journal is considerably older, having been founded as the Internationale Zeitschrift für Erziehungswissenschaften in 1931. It was commandeered by Nazi ideologues between 1935 and 1943 and briefly resurrected by its pre-Nazi editor between 1947 and 1951, before finding a permanent home at the UNESCO Institute for Education in 1955.
}

S. Roche $(\bowtie)$

UNESCO Institute for Lifelong Learning, Hamburg, Germany

e-mail: s.roche@unesco.org 
(Dave and Lengrand 1974, p. 428). We therefore see the greater emphasis on lifelong learning as a broadening rather than a narrowing of focus; as a way of adding value to our journal by encouraging a more expansive view of education and learning. We will continue to welcome submissions on all aspects of formal, nonformal and informal education, but we will give priority to those papers whose analysis adopts a perspective of lifelong learning.

To reflect this change, the IRE has been given a new cover design, which will appear with the next issue. The UIL Governing Board also decided to change the language policy of the journal. Up to now, the IRE has welcomed submissions in English, French and German. In practice, however, the vast majority have been in English and French, and we have only published six articles in German in the last twenty years. One of those six appears in this issue. With some regret, in light of our long association with the educational science communities in Germany and Austria, the Board decided that, from 2013 onwards, we can only accept and publish submissions in French and English. Moreover, whereas up to now we have also published abstracts to each article in five languages (English, French, German, Spanish and Russian), due to budget constraints it was agreed to henceforth publish abstracts only in English and French, the working languages of UNESCO, with an additional optional abstract in Spanish, Russian, Chinese or Arabic, if provided by the author.

From toddlers at kindergarten to pensioners in adult education classes, the school is where formal, non-formal and informal learning meet. It is, therefore, of central importance to the practice of lifelong learning. All five research papers in this issue deal with different aspects of schooling. We begin with Ahmed Bawa Kuyini's discussion of Ghana's recent programme of education reform. The author first lays out the deficits in Ghana's education system, as identified by international organisations and the Ghanaian government (in particular, access, quality, relevance to local needs, and weak management capacities). He raises doubts as to whether the 2007 reforms address those weaknesses, and whether the goals they set are achievable. He focuses in particular on the stated goal of making "the nation competitive in today's globalised economy which is increasingly becoming knowledge-driven". It is hard to argue with the idea of a knowledge-driven society. It conjures up visions of clean, highly-paid jobs in sparkling technology "campuses". However, as the author argues, by prioritising international competitiveness and the development of a globalised knowledge-based sector over robust local economies, countries such as Ghana are setting themselves up to fail, since this view of education "ignores the deep structural asymmetries of power between nation states in the global arena, and the unique needs of each country". This echoes the arguments of a growing group of economists, including Joseph Stiglitz, Ha-Joon Chang and Erik S. Reinert, that what the wealthy countries of the industrialised North - represented by the World Bank, the International Monetary Fund and the World Trade Organization - preach is precisely the opposite of what they practised on their own paths to development; that long before these countries developed globalised high-tech sectors, they had localised low-tech ones. It follows from this that "a strategy based on education succeeds only when combined with an industrial policy that also provides work for educated people" (Reinert 2007, p. 115). 
The issue of education for knowledge economies is also broached in our second article, but from a more practical perspective. Marcel Fouda Ndjodo, Virginie Blanche Ngah and Erick Patrick Zobo examine (in French) the changing status and profile of computer science teachers in Cameroon since the subject was added to the national secondary school curriculum in 1998. The authors begin by taking stock of the challenges inherent in introducing ICT as a subject in Cameroon - principally the absence of trained teachers, infrastructure (only 9.3 per cent of secondary schools have internet access) and equipment (high ratios of students to computers). They examine the progress and impact of computer science teachers since 1998, drawing on recent government reports. Despite certain innovations - such as the involvement of the private sector - progress in the teaching of ICT has been hampered by a chronic shortage of trained teachers. The authors take issue with the approach taken by the Cameroonian government, first in including computer science as a dedicated subject rather than incorporating ICT as a transversal element; and, second, in introducing the subject prematurely, before a large pool of trained teachers was available. By 2010/11, there were still only 300 professionally trained computer science teachers ${ }^{2}$ serving a student population of 1.2 million. So far, the gap has mostly been filled by teaching assistants and temporary teachers, who have not received professional training in ICT. Having thoroughly discussed the current role of these teachers, the authors conclude on an optimistic note with the expectation that the growing pool of trained computer science teachers will foster the spread of ICT into other areas of the secondary school curriculum.

If the attempt to directly transpose curricular elements from wealthy industrialised countries to under-resourced African schools is sometimes misguided, what can be done to ensure more authentic and locally relevant content? In a highly engaging article, authors Dennis Banda and W. John Morgan propose a solution: the application of African Indigenous Knowledge Systems (AIKS). Taking the example of the folklore of the Chewa people of Zambia, and following the theoretical framework laid down by Jakayo Peter Ocitti, the authors consider the role of folklore both in enhancing the educational experience and in promoting and sustaining cultural identity. They provide numerous examples of how different components of Chewa folklore embody traditional knowledge, and suggest how this knowledge can be applied in educational contexts. They make a convincing case for the role of indigenous knowledge as a rich complementary support for formal schooling, especially during early childhood education.

Teachers are, without doubt, the most important resource any school possesses, and, though the contexts vary greatly, every school, society and nation faces the challenge of motivating and supporting teachers. In recent years, several studies have pointed to a teacher motivation crisis in the developing world, which is undermining progress towards the achievement of development goals. Mark Wyatt begins his article by considering the challenges to teacher motivation in developing countries, including poverty, isolation, poor working conditions, lack of training, and limited support. He then examines how these challenges fit into the theoretical framework of teacher motivation. He applies, in particular, principles of self-

\footnotetext{
$\overline{2}$ This is expected to increase to 1,000 by 2015 .
} 
determination theory (SDT), emphasising the primacy of intrinsic motivation, to understand responses to the challenges experienced by teachers in developing countries. He then looks at how issues of teacher motivation have been addressed in Oman, one of the world's most rapidly developing countries. Drawing on the existing literature and original qualitative research, he examines the extent to which negative environmental influences on teacher motivation have been addressed and looks for evidence of intrinsic motivation among Omani English teachers. He concludes that teachers' psychological needs for competence, autonomy and relatedness can be met through educational policies that provide both professional development opportunities and work environments characterised by respect.

Amid mounting competition for funding and students, many European schools have come under pressure to develop distinct competitive profiles. ${ }^{3}$ This process of differentiation is similar to that which has seen numerous research and service institutions redefine themselves as "centres of excellence". Schools, therefore, emphasise certain strengths, such as music, sports or academics. This trend has developed alongside a tendency towards increased school autonomy, in which school governance has been, at least partially, decoupled from state regulation and funding. In a study of school profiling in Germany, Austria and Switzerland, author Sonja Nonte considers (in German) both the opportunities and challenges that come with the formation of school profiles, both at an individual and a systemic level. She presents examples of specific schools and school types, and offers recommendations for the application of the school profiling principle in German schools.

We round off this issue of the IRE with an article profiling the institution that has nurtured this journal for nearly six decades, the UNESCO Institute for Lifelong Learning (UIL). The author, Maren Elfert, is intimately acquainted with her subject, having worked here for eleven years as a programme specialist and public relations officer. We commissioned this article last year to mark the occasion of our Institute's sixtieth anniversary. I am very pleased with the result, and congratulate Maren on a piece of work that is comprehensive, rigorous and highly readable. This is a fitting paper to mark an important milestone for one of UNESCO's oldest institutes.

\section{References}

Dave, R., \& Lengrand, P. (1974). About the issue. Editors' Introduction. International Review of Education, 20(4), 427-429.

Faure, E., et al. (1972). Learning to be. The world of education today and tomorrow. Paris/London: UNESCO/Harrap.

Reinert, E. S. (2007). How rich countries got rich and why poor countries stay poor. London: Constable.

\footnotetext{
3 In the case of the United Kingdom, there has even been a statutory requirement since 2011 for schools to develop a distinct profile.
} 